\title{
化学物質リスク評価の教育演習に見られる ライフサイクル思考の特徵
}

\author{
山本 祐吾 1 - 松井 孝典 2 - 織田 朝美 3 - 松村 憲一 4 ・ \\ 大野 智彦 5 ・加藤 悟 6 ・東海 明宏 7 盛岡 通 8 \\ 1正会員 大阪大学大学院助教 工学研究科（干565-0871 吹田市山田丘2-1） \\ E-mail: yugo@see.eng.osaka-u.ac.jp \\ 2正会員 大阪大学大学院助教 工学研究科（同上） \\ 3 非会員 大阪大学大学院特任研究員 工学研究科（同上） \\ 4非会員 武庫川女子大学講師 短期大学部（广663-8558 兵庫県西宮市池開町6-46） \\ 5 非会員 京都学園大学非常勤講師 バイオ環境学部（†621-8555 亀岡市曽我部町南条大谷1-1） \\ 6 正会員 大阪大学大学院准教授 工学研究科（干565-0871 吹田市山田丘2-1） \\ 7 正会員 大阪大学大学院教授 工学研究科（同上） \\ 8正会員 関西大学教授 環境都市工学部（干564-8680 吹田市山手町3-3-35）
}

\begin{abstract}
本論文では，化学物質のリスク評価に見られる評価実施者のライフサイクル思考の現状と特徴を読み取 ることを目的として，評価・判定のための項目と定性的基準を策定した。その上で，大阪大学「環境リス ク管理のための人材養成プログラム」の受講生が実施したリスク評価のレポートに基づいて，リスク評価 に表出する実施者のライフサイクル思考を観察・分析した。その結果，1）物質一製品流に沿ってリスク 特定・評価を手がけ，ライフサイクル全体をマネジメントの対象とするアプローチや視点が少ないこと， 2）評価結果に基づいてリスク管理方略を多重, 多段に立案する能力とスキルの涵養には, 教育上の改善 の余地があること，3）化学物質由来のリスクが社会や組織経営に及ぼす潜在的なダメージについては, 多くの被養成者の視野におさめられていないこと，などが明らかになった。
\end{abstract}

Key Words : chemical risk assessment, life cycle thinking, risk management in organization, chemicalsproduct chain, education program

\section{1. はじめに}

近年，製造業であれ土木・建設業であれ，化学物質 の利用を伴う産業活動をおこなう企業・組織にとって, 製品含有化学物質の管理に関するRoHS指令（Restriction of the Use of Certain Hazardous Substances in Electrical and Electronic Equipment） やREACH規則（Registration, Evaluation, Authorisation and Restriction of Chemicals) への適切な対応は, 法令遵守や企業の社会的責任 (CSR: Corporate Social Responsibility) の観点からも欠かせないものとなってい る。これらのEU発の製品環境規制は，特に製造業者に 対して包括的な製品政策（IPP: Integrated Product Policy）を 推し進め, 製品ライフサイクルでの環境適合の追及を要 求する. そのため, 企業の化学物質管理にかかわる取り 組みは，単一プロセスごとの対応にとどまらず，素材や 部品産業, 組立産業, 最終消費者, さらに廃棄物処理・ リサイクル産業等との連携による化学物質一製品チェー ン (chemicals-product chain) 管理の様相を見せている。こ うしたサプライチェーン全体で化学物質管理を適切にお
こなうためには, 化学物質の特性や生産・流通・使用・ 廃棄の形態に基づいてその影響を定量的に評価・把握す ることが重要となる.

物質あるいは製品の単位フロー量あたりのライフサ イクル環境影響を評価するLCA (Life Cycle Assessment) の手法は, 主として工業製品や技術システム, 建築物, さらに元素・化合物などに適用されてきた1).しかし， 2006年に採択された「国際的化学物質管理に関する戦略 的アプローチ」（SAICM: Strategic Approach to International Chemicals Management) ${ }^{2)}$ において, 化学物質の全ライフ サイクルを通じたリスク評価と管理の重要性が述べられ たように, 化学物質管理の分野にあっても, ライフサイ クル思考に基づいたリスク評価が欠かせない。

他方，2007年6月から運用が開始されたREACH規則は， 化学物質の登録，評価，認可および制限に関する制度で あり，これまで行政機関が実施していたリスク評価が事 業者に義務付けられる，それゆえ，企業・組織の内部で は，環境経営の支援ツールとして定着したLCAをリスク 評価と統合し，化学物質のライフサイクル全体にわたる 
リスクの評価を実践できる人材が必要となる．経済産業 省によって提案された化学物質総合管理イニシアチブ3 の中では, 化学物質総合管理とは「多種の化学物質の多 様な有害性と多岐にわたる用途を踏まえ，その開発，生 産, 使用, 廃棄の全ライフサイクルにわたり, 化学物質 を扱う者全てが適切に管理を行うこと」と定義されてい る. しかし，増田ら ${ }^{4}$ 5)は，化学物質の総合的な管理に 関する学校教育や専門人材の体系的な育成が不足してお り, リスク評価を含めた化学物質管理能力の抜本的な強 化が必要であると指摘している.

こうした中, 文部科学省科学技術振興調整費・新興 分野人材養成「環境リスク管理のための人材養成」プロ グラムの)（2004～2008年度，研究代表 : 盛岡通，現在は

「環境リスクマネジャ養成プログラム」として継続運 営）では, リスク評価や管理，さらにリスクコミュニケ ーションに関する理念や知恵の体系，実践スキルを教授 する講義・演習を運用している. 図-1は，2007年度当時 のカリキュラム構成である.この教育プログラムでは, 正規の大学院生に加え, 企業・組織に属する社会人も数 多く受講している.

同じ新興分野人材養成の枠組みには，具体的な実務 上の課題にリスクマネジメントの手法を的確かつ総合的 に適用できる人材の育成を目的とした横浜国立大学「高 度リスクマネジメント技術者育成ユニット」7) (現在は 副専攻プログラム「安心安全マネジメント」として継 続）や，化学物質や生物によるリスクの評価・管理を対 象としたお茶の水女子大学「化学・生物総合管理の再教

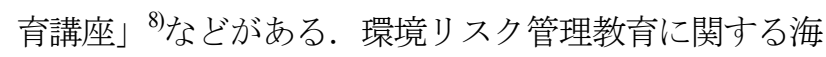
外の事例9)としては, 環境・健康に関寸る幅広い領域を 対象に，分野横断的なintegration ability（統合力）を養成 するDivision of Environmental Health and Risk Management, Scho ol of Geography, Earth and Environment, University of Birmingham
の取り組みや, public healthとoccupational healthを研究・教 育の中心に据えつつ, 環境経済, コス卜便益分析, 倫理 哲学などを幅広くカバーしたリスク管理教育を手がけて いるMiddlesex UniversityのCenter for Decision Analysis and Risk Managementなどがある.

化学物質の一般的なリスク評価は，まず対象物質を 選定して, その排出源解析, 暴露解析, リスク判定をお こなうという手順を基本とする. これに対して，化学物 質の全ライフサイクルを通じたリスク評価と管理を実行 するためには，環境中への化学物質の漏出や散逸の源泉 であるモノの流れ, 寸なわち産業システムにおける化学 物質一製品チェーンに沿って, 物質の移動や排出を追 跡・評価する必要がある。その意味では, 横浜国立大学 は, ライフサイクルを通じた化学物質のトータルリスク 評価に関する教育・研究を手がけている点で特徽的であ る.

そこで本論文は，先述した大阪大学の教育プログラ ムにおいて実施されたリスク評価の演習事例を題材にし て，化学物質のリスク評価に見られる評価実施者のライ フサイクル評価および管理志向の現状と特徵を読み取る ことで，管理策の構築・提案を含めたリスク評価スキル のレベルを明らかにすることを目的とする．まず，企 業・組織の事業活動に伴う化学物質のリスク評価をおこ なう際に考慮すべきLCA的視点を明確にする. 次に, そ れぞれがリスク評価事例においてどの程度考慮ないし実 践されているかを判定するための基準を策定する. 最後 に，以上の現状分析と把握を通じて，実施者に前提知識， スキルとして具備されているライフサイクル思考を推察 し, 化学物質総合管理を実践できる専門人材の育成強化 を図るために，現在の環境リスク教育プログラムをどの ように改善, 高度化するべきかについて示唆を得ること を目指す。

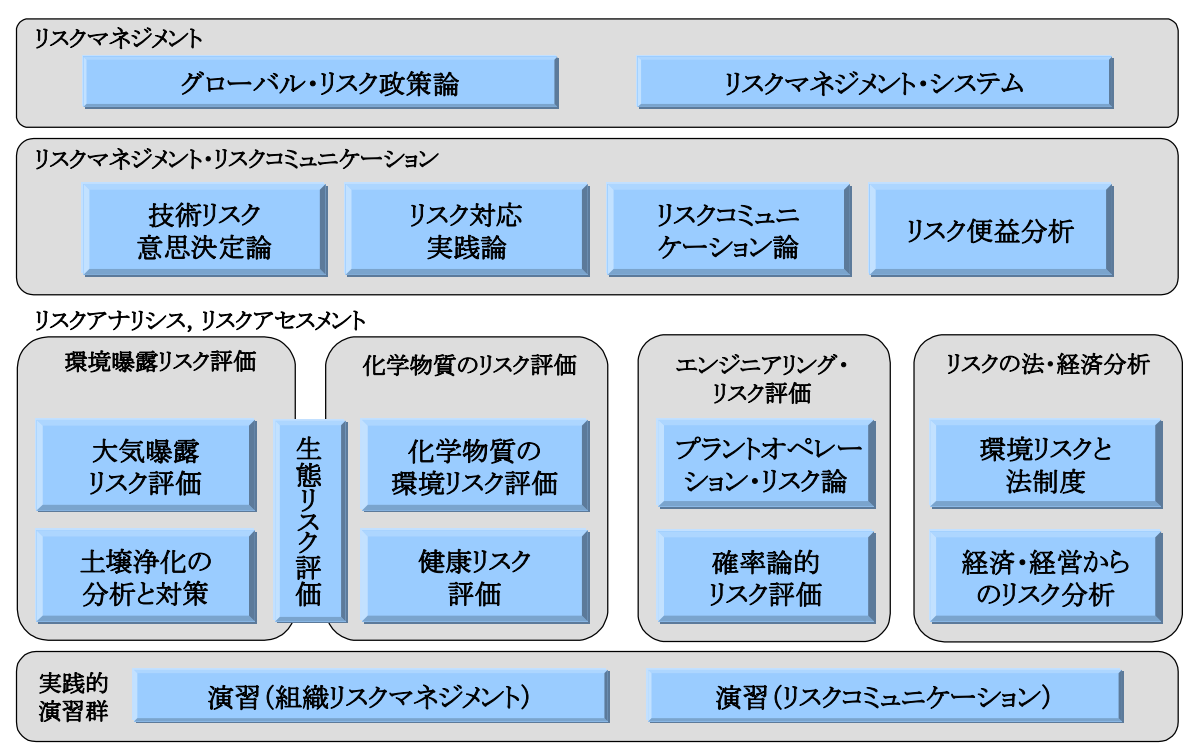

図-1 「環境リスク管理のための人材養成」プログラムのカリキュラム構成（2007年度） 


\section{2. 分析方法}

\section{（1）対象とする題材}

本論文では，「環境リスク管理のための人材養成」 プログラムの一科目として実施された「化学物質の環境 リスク評価」（講師：東海明宏，産業技術総合研究所・ 東野晴行氏）において，社会人を含む受講生が2007年度 に実際におこなったリスク評価演習のレポートを用いて, ライフサイクル思考の観察・分析をおこなう。講義では, リスク評価および管理の考え方や手順, 実例の説明, ソ フトウェアを用いたリスク評価手法の解説, リスクトレ 一ドオフ解析の理念と方法の説明などがなされた（図一 2) 。また，EUの “Risk Assessment Report” ${ }^{10}$ を紹介し, 製品ライフサイクルに沿った環境排出データの収集につ いて紹介している.

演習課題は「公開されているソフトウェアを使いな がら，事業所等から排出される化学物質によるリスク評 価を実施し, 最終的にリスク評価書を作成すること」で あり, レポートでは問題の設定, 評価対象物質や対象地 の選定，影響が及ぶ経路の特定，評価の実施，およびリ スク管理に向けた提言をまとめることが課された。この 課題は第1回目の講義で提示され, 約1ヶ月半後に実施計 画書が提出された. その後, 評価実施者間でのレビュー を経て, この提出から約2ヶ月後に最終のリスク評価書 が提出された．また，対象物質や評価範囲などは評価実 施者の視点や捉え方に委㸚られ，レポートの分量等に関 しても特に指定されなかった.

分析対象としたレポートの総数は35, 表紙と目次を除

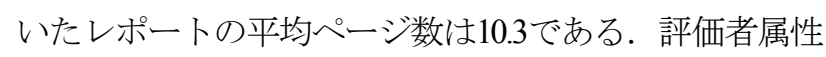
は, 大学院生 : 11名, 製造業: 10名, 建設業: 2 名, サ 一ビス業: 3 名, 教育・学習支援業 : 3 名, 金融・保険 業: 1名, 卸売・小売業: 1 名, 電気・ガス・熱供給・水 道業：1名，公務：3名である. 年齢別では，20代：13名， 30 代: 5名, 40代: 5名, 50代: 7名, 60 代以上: 4名, 不 明 : 1名である.

\section{（2）視点と枠組み}

先述したSAICMでは, 化学物質のライフサイクルを 通じたリスク評価と管理の重要性のほかに，以下の点が リスク削減に関する目的として挙げられている.

・労働者を含むヒト健康, 環境へのリスクを最小化す ること

- 化学物質に対する人や生態系の脆弱性, 曝露しや寸 さを考慮すること

- 適切な科学的理解と社会経済分析に基づいた包括 的・効率的・効果的なリスク管理戦略を実施するこ と
また，有害物質排出による影響を評価するとき，リ スク評価とLCAにおける運命予測および潜在的影響分析

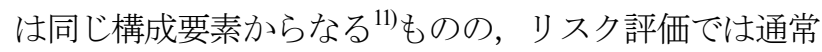
現象の結果としての毒性リスクに焦点が当てられるのに 対して, LCAでは原則的に現象の原因として, システム から放出されるあらゆる環境影響因子が網羅されるとい う違いがある。この点に関して, Matthewsら ${ }^{12}$ は次のよ うに指摘している.

・リスク評価によって有害物質への曝露による健康リ スクが特性化，定量化されるが，政策的含意が明確 でない.リスク評価を政策的な結論や助言に転換す る際に，分析者はLCA指針を追及すべきである.

・どの対策ならば別のところで高リスクをもたらさず, より低リスクとなるかを明らかにするために，LCA を含む広範な枠組みが必要である.

- 他方, LCAでは, 環境排出インベントリーを健康お よひ環境インパクトに変換する段階で困難が伴うが, インパクト評価がなされなければ，政策立案者は 「どの化学物質が，どの媒体によって，どこで排出 されるか」にかかわらず，すべての放出物が等しく 有害であるなどのシンプルなルールに立ち戻らねば ならなくなる.

・したがって, LCA側でも, 排出インベントリーに関 して過度に単純化した仮定を越えるためには, リス ク評価の助けが必要となる.

これらを踏まえて考えると, リスク評価において必 要とされるLCA的視点としては, a) どの化学物質がど こで排出されるかといった「ライフステージや放出物質 の俯瞰性・網羅性」，b）媒体やエンドポイントなど 「リスクシナリオの多様性」，c）リスク被受者の脆弱 性の違いや，そのリスクの持つ社会経済的意味付けを考 慮するなどの「リスク総合評価のレベル」，d）リスク 評価結果に基づき，対抗リスクの調整を含んだリスク管 理戦略を提案するなど「リスク管理に関する助言の熟 度」,が挙げられよう。

こうしたライフサイクル思考をリスク評価の実践事 例から読み取るためには，評価項目を具体的に設定した 上で，ライフサイクル的思考やその水準を判定するため の基準を定めなければならない，そこで，以下の判定項 目および定性的基準を策定し，それらに沿って各レポー 卜を分析する. 分析フレームは図-3の通りである. なお， リスク評価の進め方はその目的や採用した分析手法によ って一様ではなく, はじめに対象物質や排出源を特定す るものもあれば, 産業活動範囲や地域などの空間領域を 限定することもある. したがって, リスク評価とLCAの 統合的なアプローチが実装されていないことをもって, その手続きが誤りであるとするものではない. 


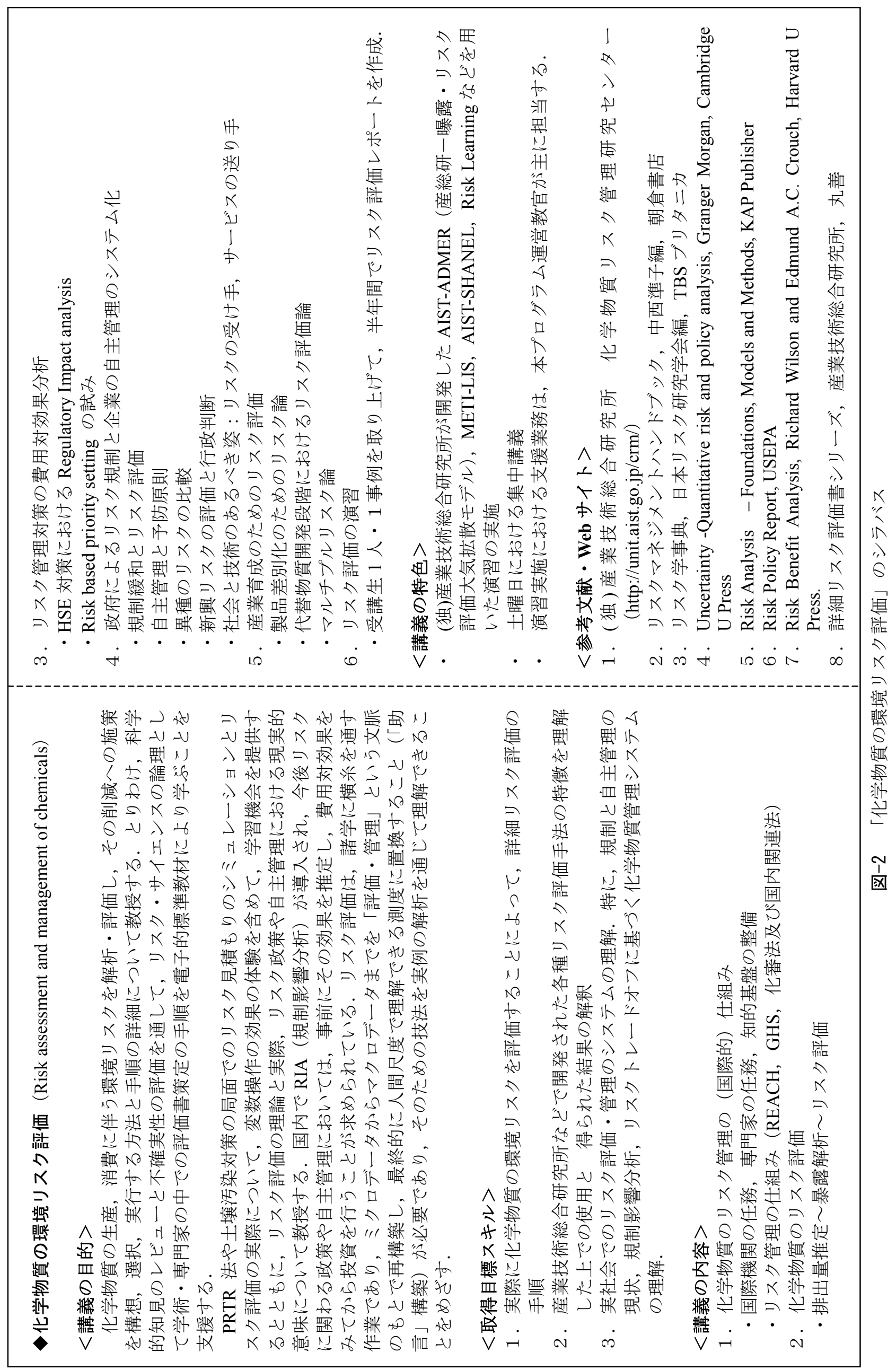




\section{a) ライフステージおよび排出インベントリーの網羅性}

化学物質のリスク評価は，物質の用途や環境への排 出源, 伝播・曝露経路およびエンドポイントを特定し, その一連の過程での影響を評価の対象とする。 その際, 化学物質一製品フローの側に着目すれば，そのリスク評 価は生産・加工から流通, 利用, 廃棄に至るライフサイ クルに沿った定量化のプロセスであるとも解釈できる.

ライフサイクルにわたる化学物質の多様なリスクを扱う とき，全体のリスクを把握し，より大きなリスクを有す ると思われる事項から優先して評価, 管理する必要があ る ${ }^{13)}$. したがって，そこでのリスク評価は，その上流工 程であるライフサイクルの範囲や排出インベントリーの 網羅性を伴う必要がある. そこで, 財・サービスのフロ 一に随伴する化学物質のライフステージを複数網羅して, 排出源を特定しているかどうかについて，以下の判定基 準を設定した。

なお，a）およびb）では，あらゆる可能性を網羅した 上で，想定される影響の強さや大きさから定性的ないし 定量的に優先順位づけし, 対象を選定している場合は 「**」に該当するとみなす.

\section{a-1 ライフステージの網羅性}

* : 単一のライフステージを評価対象にしている. (ラ イフサイクル思考の把握を狙いとしているので，複数の 発生源を対象としている場合であっても, それが同一ス テージのものであれば，ここに該当するとみなす。）
** : 化学物質一製品フロー上の複数ライフステージにお ける発生源を評価対象としている。（環境中挙動の過程 にかかわるライフステージは該当しないものとする） *** : 上記**に加えて, ライフサイクル全体を俯瞰した 上で対象とするライフステージを選定しているなど，さ らに特筆すべき事項がある.

a-2 放出物質の網羅性

*: 単一物質を評価対象としている.

** : 影響物質と考えられる複数の物質を評価対象として いる.

***：上記**に加えて, 評価対象候補を網羅した上で優 先物質を選定するなど，さらに特筆すべき事項がある.

b）曝露評価におけるリスクシナリオの多様性

対象物質, 評価範囲などはリスク評価の目的や評価 者の関心によって変わるが，ある事業活動に伴う化学物 質のリスク評価をおこなう場合，少なくともスクリーニ ングの段階では単一物質の単一影響のみに着目するので はなく, 複数 (異種) の物質, 環境媒体・摂取媒体, 曝 露経路, エンドポイントを取り上げて, 多様なリスクシ ナリオを想定した上で，リスクを総合的・包括的に解釈 する必要があろう。これは, LCAのインベントリ一分析 において，大気污染や水質污濁，地球温暖化，資源消費 などにかかわる投入と産出が対象項目とされることに類 似する. そこで，ここでは曝露評価における媒体・経路 およびェンドポイントの多様性に関して，以下の判定基

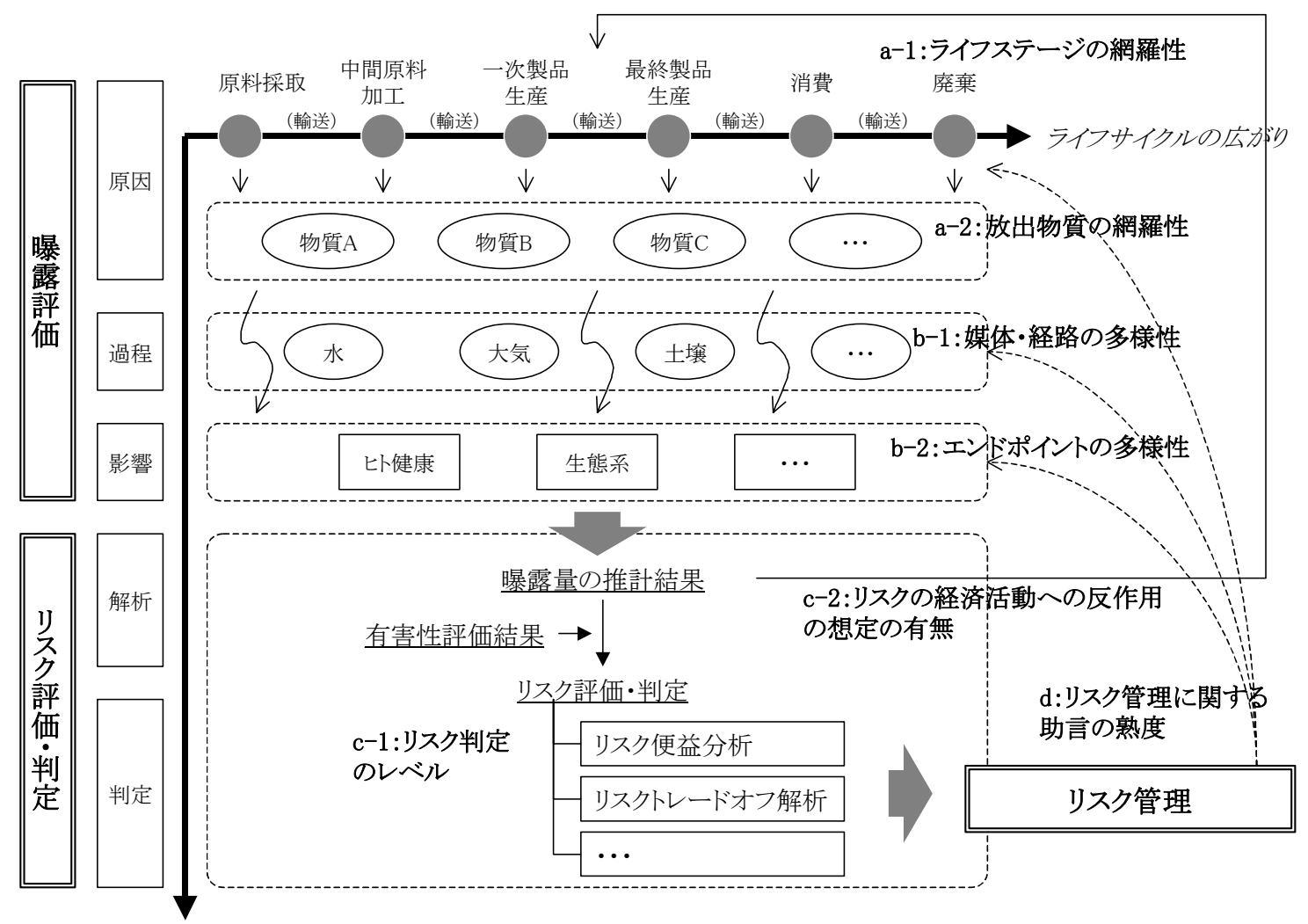

因果連鎖の網羅性, リスク評価の手順

図-3 分析の枠組み 
準を設定した.

b-1 媒体・経路の多様性

*: 単一媒体による曝露経路を評価している.

** : 複数の媒体を介した影響伝播を扱い, 評価している.

*** : 上記**に加えて, 想定される曝露経路を網羅した

上で優先経路を選定するなど，さらに特筆すべき事項が ある。

b-2 エンドポイントの多様性

* : ヒト健康, 生態などのうち, 単一のエンドポイント を観察および分析対象としている.

** : 異種の複数エンドポイントを観察および分析対象と している.

***：上記**に加えて，想定されるエンドポイントを網 羅した上で優先項目を選定するなど，さらに特筆すべき 事項がある.

\section{c）リスク総合評価のレベル}

曝露評価と有害性評価の結果に基づくリスク判定で は, 人・集団の脆弱性の考慮, 社会経済分析やリスク便 益分析の実施，物質代替等によるリスクトレードオフの 解析などの総合評価をおこない，意思決定につなげる行 為が不可欠となる.また，化学物質の利用を伴う産業活 動をおこなう企業・組織は, 社会的責任上の必要性など から，自社製品・サービスのチェーンに随伴する化学物 質による環境・ヒト健康・生態系へのインパクトを定量 的に把握することに関心を寄せている. しかし，化学物 質を扱う組織にとっては，健康・生態リスクが経営リス クに直結するというよりは，その化学物質の環境基準值 や製品含有規制への非適合，環境制約の高まりによる事 業継続性の低下などを介して，組織経営への劦威（ある いは逆にビジネス機会) として間接的に顕在化すること が経営上のリスクとなろう。そこで，発現したリスクが 排出主体の経済活動に及ぼす反作用の想定を含めた，リ スク総合評価・判定のレベルに関して，以下の判定基準 を設定した。

c-1 リスク判定のレベル

* : 曝露評価および有害性評価（引用）の結果から，リ スク解析を実施している.

**：リスク被受者の脆弱性の違いの考慮やリスク便益分 析等を実施した上で，リスク判定している.

*** : 上記**に加えて, 前提条件や評価範囲, 使用デー 夕の精度など，曝露評価や有害性評価の結果に影響を及 ぼす不確実性について考察や感度分析をおこなうなど, 特筆すべき事項がある.

c-2 リスクの経済活動への反作用の想定の有無

*: 想定・考察していない.
**：ヒト健康・生態リスクを保有することが, その原因 物質を排出している主体の組織経営に影響を及ぼすこと を想定している.

*** : 上記**に加えて, 具体的な伝播過程や影響に触れ ながら定性評価・考察している, 影響の大きさに関する 科学的知見や社会的事例のレビュ一等を通じて, 組織リ スクについて解釈・言及しているなど，特筆すべき事項 がある。

d）リスク管理に関する助言の熟度

産業構造審議会化学・バイ才部会の化学物質管理企画 小委員会 ${ }^{14)}$ は, リスクベースの化学物質総合管理を担い うる人材，すなわち有害性評価，曝露評価，リスク評価 を進め，さらにそれに基づいてリスク管理を推進する知 恵や技能を有する人材の育成と確保が必要になると述べ ている.この点に関して，LCAが製品システムの改善や 製品設計の見直しなどに対して科学的・客観的根拠を与 える手法として用いられているように，リスク評価は管 理行為のための手段であるので，そこではリスク管理の ために何が操作変数となりうるか, どの断面に政策介入 しうるかの解析と理解が肝要である. それは，化学物質 の排出〜移動〜曝露の断面で大別すると，1）問題の源 泉, すなわち排出源での発生抑制型の未然防止対策,

2）移動・拡散の過程での処理や遮断といったエンドオ ブパイプ型の対策，3）エンドポイント側での行動パタ 一ンやライフスタイルの操作による対策，に分けられる. そこで，リスク評価の結果に基づいた，さまざまな関係 主体に対するリスク管理のための助言に関して，その熟 度の判定基準を以下のように設定した.

d リスク管理に関する助言の熟度

* : リスク評価結果の説明と考察にとどまっている.

** : 政策介入しうる断面を明らかにしながら，具体的な リスク管理策を提案している.

***：上記**に加えて，対抗リスク（目標リスクの削減 によって生じる別の新たなリスク）を評価・考察してい る，対策オプションを上流・中流・下流で広く取り上げ て比較評価しているなど，特筆すべき事項がある.

\section{3. 分析結果および考察}

以上の7つの側面と基準に沿ってリスク評価演習のレ ポートを判定した結果を表-1に示す.また，その集計結 果は図-4の通りである.

\section{(1) 分析結果}

a）a-1：ライフステージの網羅性

産業技術総合研究所が開発したADMER ${ }^{15)}$ (曝露・リ 


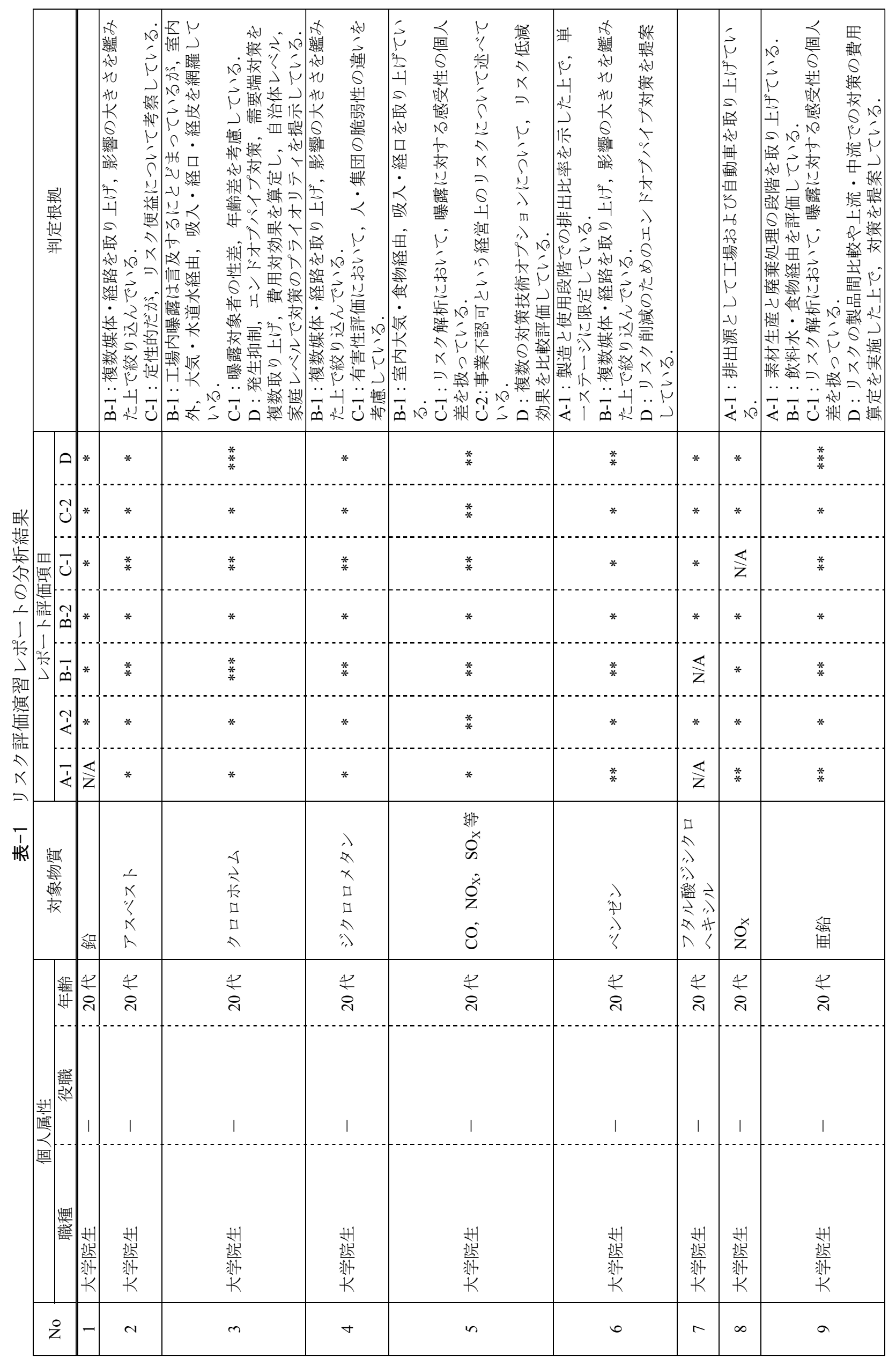




\begin{tabular}{|c|c|c|c|c|c|c|c|c|c|c|c|c|}
\hline 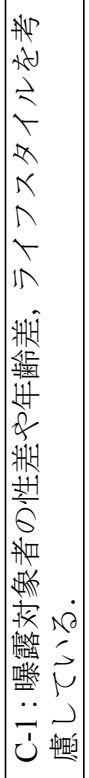 & 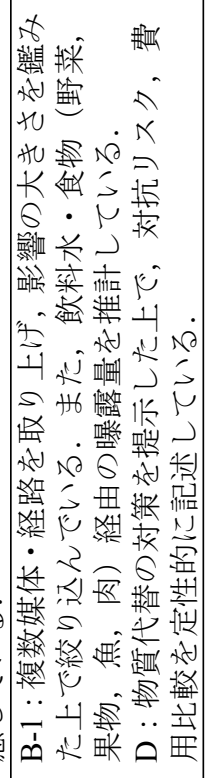 & 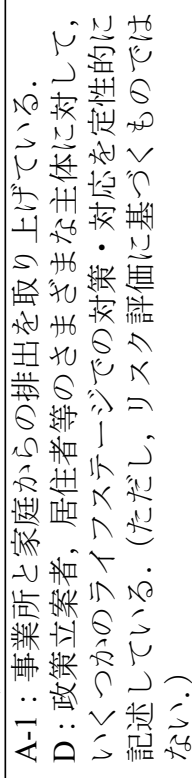 & 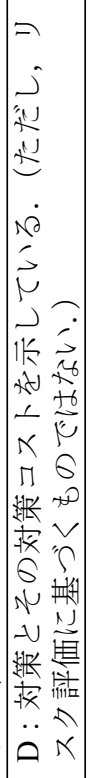 & 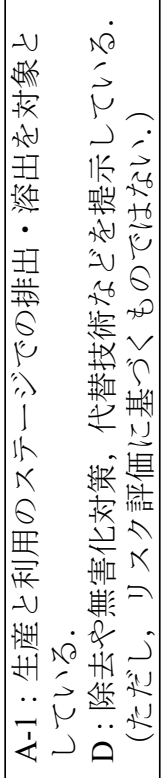 & 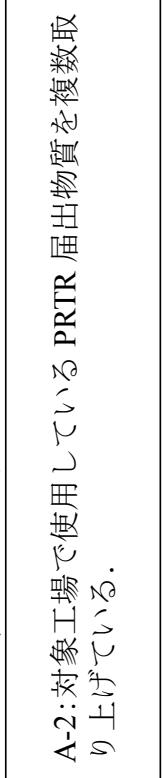 & & & 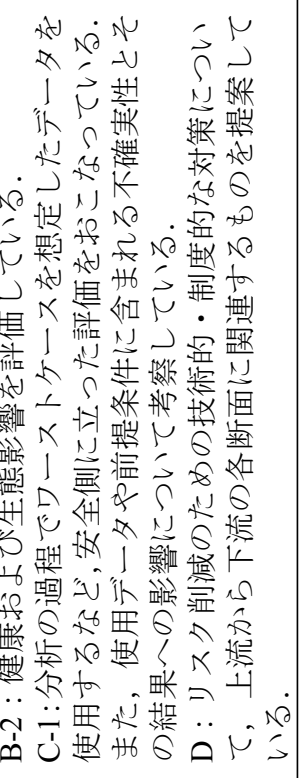 & & 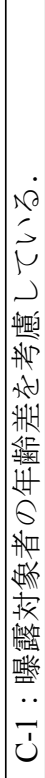 & 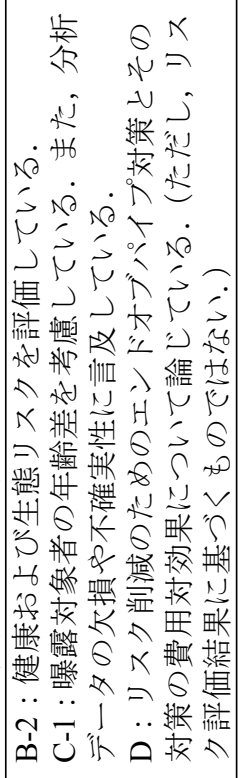 & \\
\hline$*$ & * & $\stackrel{*}{*}$ & * & 羍 & $*$ & $|\mathbb{z}|$ & $\mathbb{Z}$ & $\underset{*}{*} \underset{*}{*}$ & $*$ & * & $\stackrel{*}{*}$ & * \\
\hline$*$ & * & * & $*$ & * & * & $*$ & $\mathbb{Z}$ & $*$ & * & * & * & * \\
\hline$*$ & * & * & * & $\overleftrightarrow{Z}$ & $*$ & $\mathbb{Z}$ & $\mathbb{Z}$ & $\underset{*}{*}$ & $*$ & $*$ & $\stackrel{*}{*}$ & * \\
\hline$*$ & * & * & $*$ & $*$ & * & $\overleftrightarrow{\square}$ & $\mathbb{Z}$ & * & * & * & * & * \\
\hline$*$ & $\stackrel{*}{*}$ & * & $*$ & 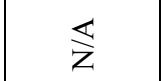 & $*$ & 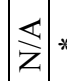 & & * & $*$ & * & $*$ & * \\
\hline$*$ & * & * & $*$ & * & * & * * & * & * & * & * & * & * \\
\hline$*$ & 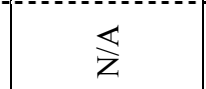 & $*$ & $*$ & * & * & 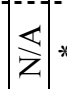 & & $\underset{\mathrm{Z}}{\overleftrightarrow{\mathrm{Z}}}$ & $\overleftrightarrow{\mathbb{Z}}$ & $\overleftrightarrow{\breve{z}}$ & $\overleftrightarrow{\mathrm{Z}}$ & * \\
\hline $\begin{array}{l}\vec{H} \\
\stackrel{H}{2} \\
\stackrel{2}{2}\end{array}$ & 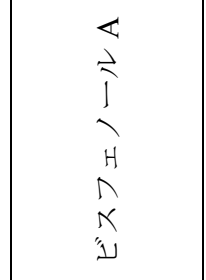 & 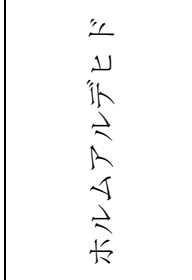 & 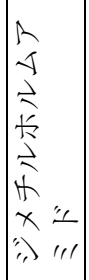 & 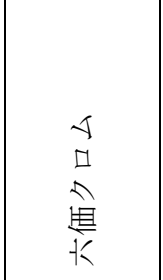 & 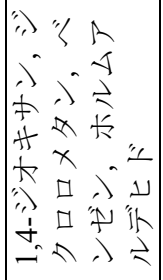 & 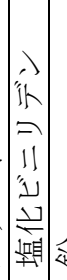 & & $\begin{array}{l}\vec{i} \\
\vec{a} \\
\hat{k} \\
\hat{k}\end{array}$ & 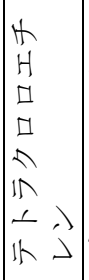 & 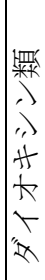 & 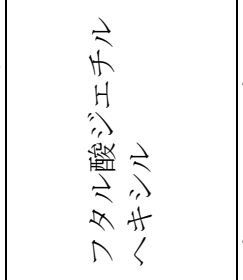 & 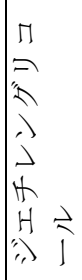 \\
\hline $\begin{array}{l}\text { से } \\
\stackrel{\sim}{*}\end{array}$ & $\begin{array}{l}\underset{\sim}{*} \\
\stackrel{i}{2}\end{array}$ & $\begin{array}{l}\text { स } \\
\text { in }\end{array}$ & $\frac{4}{8}$ & $\begin{array}{l}\underset{n}{*} \\
\text { in }\end{array}$ & $\begin{array}{l}\text { tr } \\
\text { in }\end{array}$ & $\mid$\begin{tabular}{l}
$\mathbb{P}$ \\
\hdashline \\
8
\end{tabular} & $\begin{array}{l}\frac{2}{2} \\
\vdots \\
n\end{array}$ & $\underset{⿱}{\stackrel{P}{q}}$ & 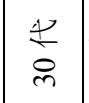 & $\begin{array}{l}\Psi \\
0 \\
0\end{array}$ & $\begin{array}{l}\underset{n}{*} \\
\text { in }\end{array}$ & $\begin{array}{l}\text { स } \\
\text { in }\end{array}$ \\
\hline I & 1 & 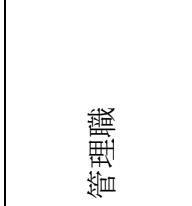 & 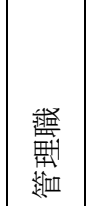 & 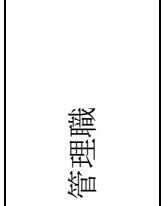 & 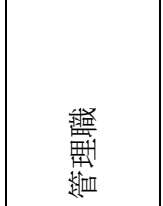 & 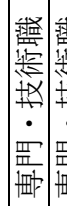 & & 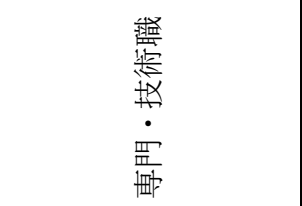 & 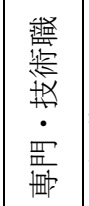 & 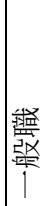 & $\overleftrightarrow{z}$ & 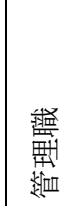 \\
\hline 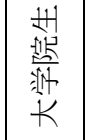 & 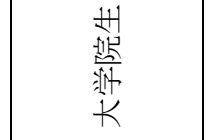 & 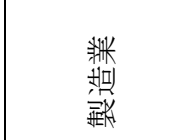 & 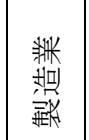 & 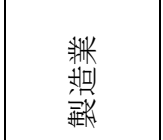 & 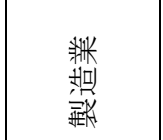 & 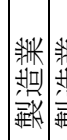 & & 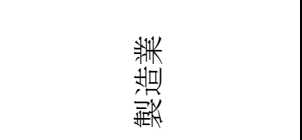 & 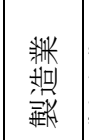 & 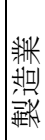 & 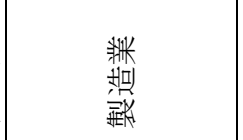 & 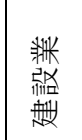 \\
\hline 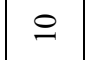 & $=$ & $\simeq$ & $\stackrel{m}{\sim}$ & $\Xi$ & $\cong$ & $\div$ & \pm & $\stackrel{\infty}{-}$ & $\stackrel{2}{ }$ & 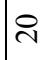 & $\vec{\sim}$ & $\widetilde{\Xi}$ \\
\hline
\end{tabular}




\begin{tabular}{|c|c|c|c|c|c|c|c|c|c|c|c|c|}
\hline & 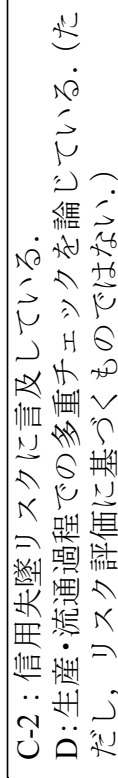 & 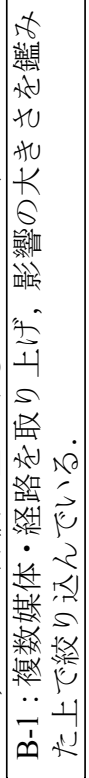 & & 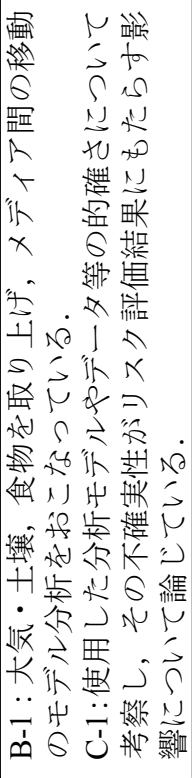 & & 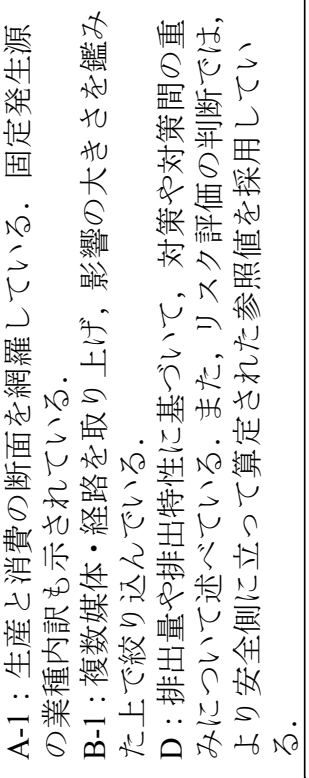 & & & 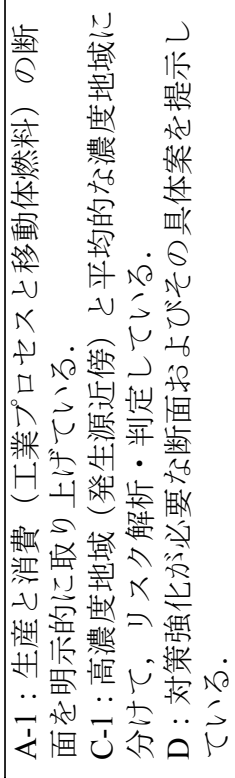 & 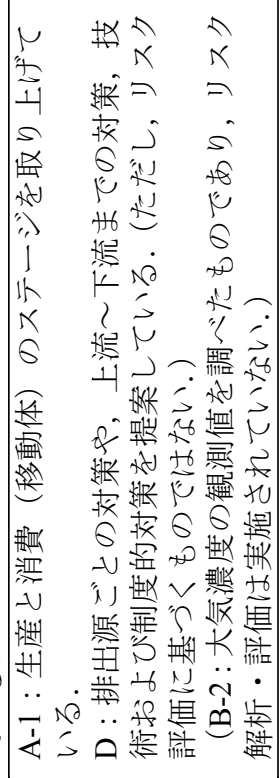 & 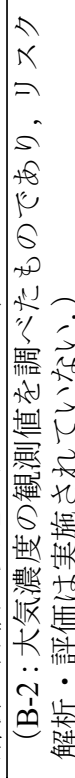 & \\
\hline$\overleftrightarrow{z} \mathbb{z}$ & $*$ & $\overleftrightarrow{z}$ & 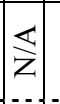 & $*$ & $*$ & * & * & $\overleftrightarrow{Z}$ & $*$ & * & $\overleftrightarrow{Z}$ & \\
\hline * & $*$ & * & $\overleftrightarrow{\square}$ & $*$ & * & $*$ & $*$ & * & * & $*$ & $*$ & 檽 \\
\hline 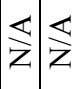 & $\overleftrightarrow{\mathrm{z}}$ & $\overleftrightarrow{Z}$ & $\overleftrightarrow{z}$ & * & * & * & * & * & $*$ & $\overleftrightarrow{Z}$ & $\overleftrightarrow{Z}$ & $\therefore$ \\
\hline$\overleftrightarrow{z} *$ & $*$ & * & * & $*$ & * & * & * & * & $*$ & * & * & 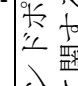 \\
\hline$* \mathbb{Z}$ & $\overleftrightarrow{z}$ & $*$ & * & * & * & $*$ & * & * & $*$ & $*$ & * & $\begin{array}{l}H \\
\ddot{N} \\
\tilde{N}\end{array}$ \\
\hline * $\quad *$ & $*$ & * & * & $*$ & * & $*$ & * & $*$ & $*$ & $*$ & * & $\frac{11}{4}$ \\
\hline$* *$ & $*$ & $\overleftrightarrow{z}$ & $\mathbb{Z}$ & $\overleftrightarrow{\mathrm{Z}}$ & $\overleftrightarrow{\mathrm{z}}$ & $*$ & * & * & $\stackrel{*}{*}$ & * & $\overleftrightarrow{Z}$ & $\left.\right|_{x \rightarrow 4} ^{14 t}$ \\
\hline 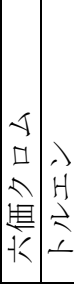 & 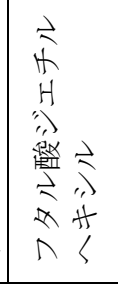 & 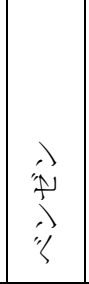 & $\mid \begin{array}{l}\mathbb{0} \\
0 \\
0 \\
2\end{array}$ & 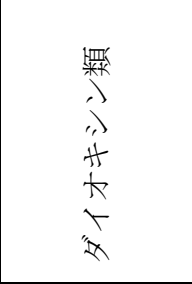 & $\left|\begin{array}{l}0 \\
0 \\
0 \\
2 \\
2\end{array}\right|$ & $\begin{array}{l}\vec{H} \\
\vec{H} \\
\stackrel{2}{2}\end{array}$ & 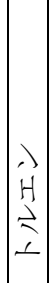 & $\begin{array}{l}4 \\
\square \\
R \\
\text { 堅 } \\
\dot{K}\end{array}$ & $\begin{array}{l}\vec{H} \\
\stackrel{H}{2} \\
\vec{I}\end{array}$ & $\stackrel{0}{Z}^{*}$ & $\stackrel{0}{Z}^{x}$ & 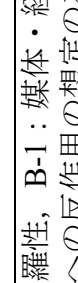 \\
\hline 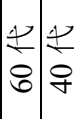 & $\underset{+}{\stackrel{P}{Q}}$ & $\underset{\sim}{\stackrel{\sim}{2}}$ & 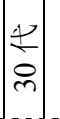 & $\underset{\text { i }}{\stackrel{*}{2}}$ & $\overleftrightarrow{\mathrm{z}}$ & $\stackrel{4}{\stackrel{4}{q}}$ & $\mid \begin{array}{l}\mid r \\
q \\
q\end{array}$ & $\frac{4}{8}$ & $\underset{\infty}{\stackrel{\psi}{m}}$ & 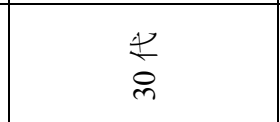 & $\frac{4}{8}$ & $\mid$ \\
\hline 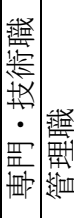 & 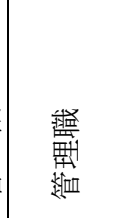 & 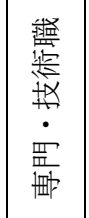 & 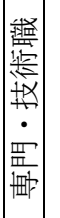 & $\begin{array}{l}\frac{F}{6} \\
\hat{v} \\
N\end{array}$ & 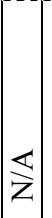 & 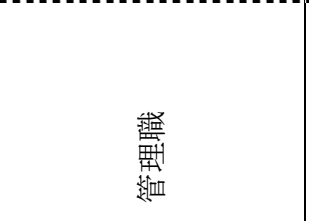 & 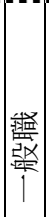 & $\overleftrightarrow{z}$ & 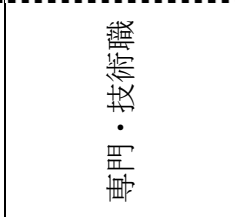 & 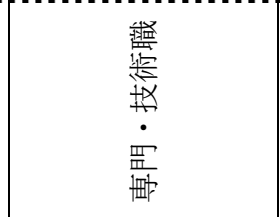 & $\begin{array}{l}\frac{ \pm}{6} \\
\sqrt[N]{2}\end{array}$ & 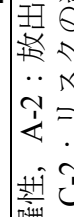 \\
\hline 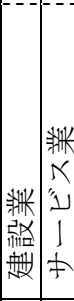 & 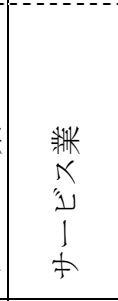 & 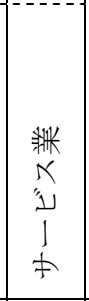 & 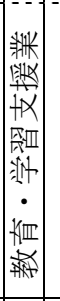 & 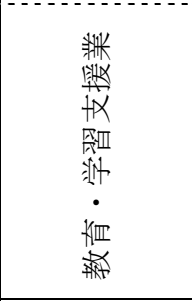 & 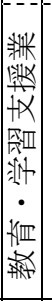 & 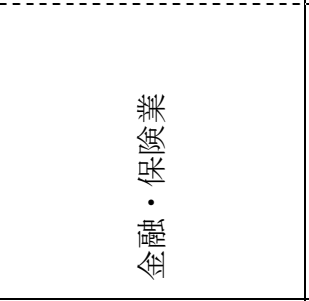 & 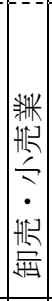 & 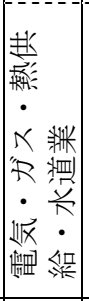 & 督 & 䔝 & 㮡 & 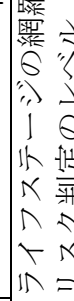 \\
\hline$\approx \stackrel{\sim}{\sim}$ & $\ddot{\sim}$ & i & $\hat{\sim}$ & $\stackrel{\infty}{\sim}$ & iे & ిల & $\bar{m}$ & లె & $m$ & ఉా & $m$ & \\
\hline
\end{tabular}




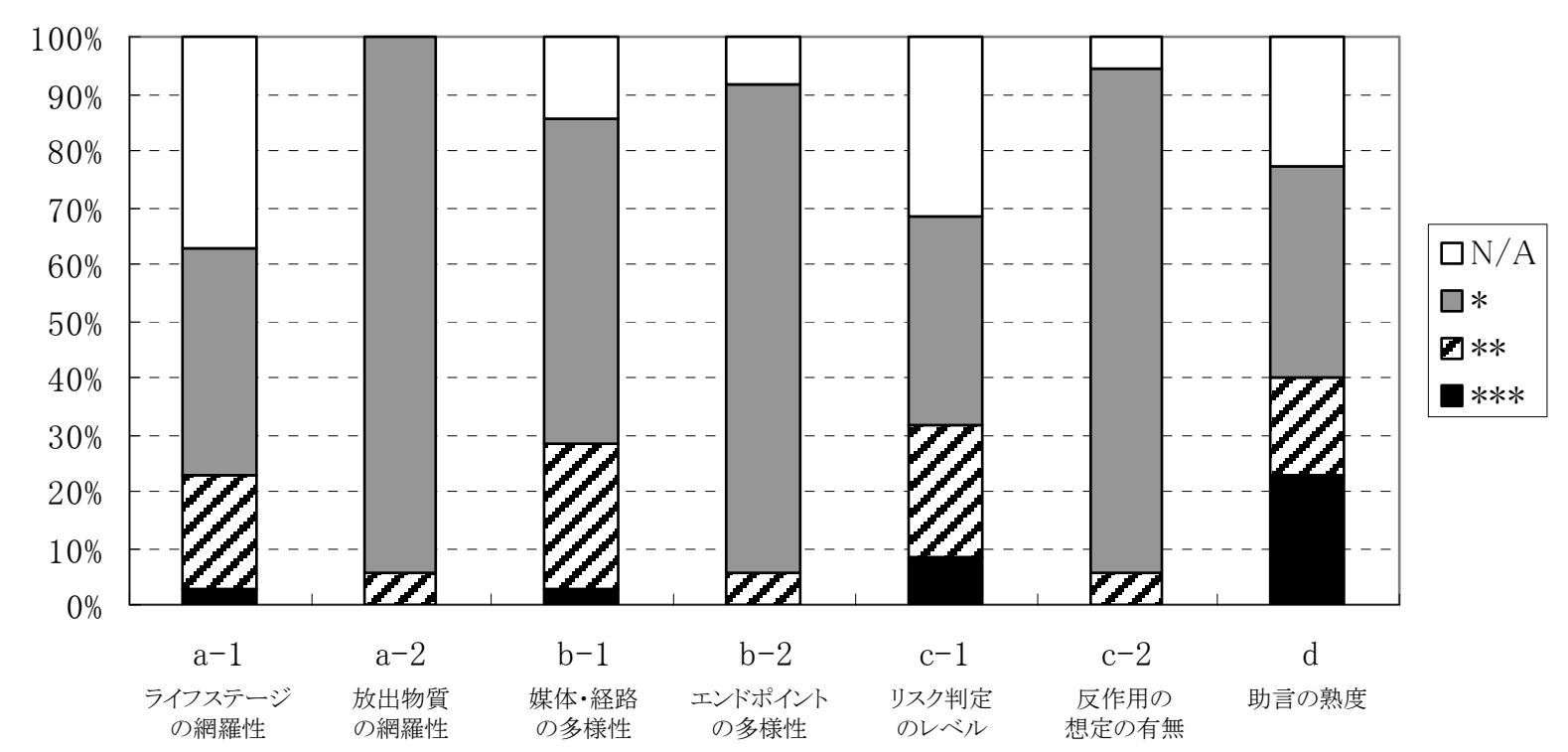

図-4 各判定項目の集計結果

スク評価大気拡散モデル） やSHANEL ${ }^{16)}$ (水系暴露解析 モデル）などのツールを用いた分析が多く見られたが， そこではPRTR届出データから対象化学物質の排出源お よび排出量を得ている. そのため, ライフサイクル的な 視点からの意図にかかわらず，異なるライフステージの 複数事業所が含まれる結果となっている. しかし，工業 プロセスから環境中への放出以外に，加工・生産された 化学物質が製品に含有されて移動するフローを追跡し, 各ライフステージからの排出を意識的に体系化し，評価 対象に組み込んだレポートはわずかに1報（No.33）であ った.

極論すれば，評価者が着目した個別生産プロセスか ら排出される化学物質の環境運命予測とリスク評価への 関心は強いものの，産出物（原料や製品）の産業利用や 流通・消費，廃棄のチェーンに随伴するリスクをライフ サイクルで全面的，一体的に評価・管理するという思考 は，現状では浸透していないと言える.

b） a-2 : 放出物質の網羅性

多くのレポートが，着目する物質を1つ選定してから リスク評価していることが分かる. 逆に複数の物質を取 り上げているものは，対象とする空間領域をはじめに設 定したケース（No.5）と，特定工場での事業活動総体を 評価対象としたケース（No.15）の2報であった.

マテリアルフロー分析（MFA: Material Flow Analysis）と 呼ばれる手法には，一般に特定物質・製品に着目し，そ のフローに沿って排出される環境負荷を計量するアプロ 一チ（LCA）と, 事業所や地域といった物質代謝体に着 目し，その境界を出入りするエネルギーや資源を評価対 象とするアプローチがある. 今回の事例の多くは前者に 該当すると捉えることができるが，先述したように，そ こでの主たる関心は個々のプロセスから放出された原因
物質の動態であり, 化学物質の生産と消費の流れに沿つ て環境負荷やリスクを追跡しようとする姿勢はほとんど 観察されなかった。

\section{c) b-1：媒体・経路の多様性}

考えられる媒体・経路を幅広く取り上げ，評価して いるレポートは4報（No.3，5，9，28）であった。しか し，他においても排出や移動の経路を俯瞰した上で，評 価対象物質の特性や排出量, 排出形態等に関する知見や データに基づいて媒体・経路を選定している手続きが見 られた（No.2，4，6，11，26，30）。

B-2およびC-1にも共通寸るが，対象媒体や経路の絞り 込みに必要な情報の入手が比較的容易であり, 分析ツー ルを含めた方法論と手順が確立されている評価プロセス に関しては，手順に沿って一連の評価を実行するスキル が習得されていると解釈できる.

\section{d） b-2 : エンドポイントの多様性}

複数のエンドポイントを設定し, 評価しているレポ 一トは2報（No.18，21）であった. また，評価には着手 していないものの, 異なるエンドポイントに与える影響 に言及しているものも8報（No.3，4，6，8，9，10，11， 26）あり，先の 2 報と合わせて全体の約 $29 \%$ あっあた.

したがって，多様であれば良いとは一概に言えない が，エンドポイントの取り上げ方が対象物質の有害性等 を鑑みて妥当であるかどうかについて，俯瞰的視野から 解䣋寸るプロセスを補強する必要があるだろう，将来的 にREACH規則がより厳格に運用されることになれば, ヒト健康や生態への影響を含め, 化学物質がライフサイ クル全体を通じて安全に使用できることの立証が求めら れるため, 評価エンドポイントの設定に関する合理的判 断の重要性は増すと考えられる. 
e) c-1 : リスク判定のレベル

ここでも，ヒ卜健康リスクの評価ツールであるRiskLearning ${ }^{17)}$ ，損失余命の尺度に基づいてリスクを計算す るRiskCaT-LLE ${ }^{18)}$ な゙，産業技術総合研究所が開発した ツールを用いることにより，個人差や年齢差など曝露に 対する感受性を考慮した上でリスク判定しているレポー 卜が7報（No.3，4，5，9，10，20，21），曝露濃度に差 のある発生源近傍と離れたエリアを分けて評価している ものが1報（No.33），定性的ではあるがリスク便益を考 察しているものが1報（No.2）確認された（全体の約 26\%）。このような子どもや高齢者など感受性の高い集 団に対する評価は，政策的な意思決定や制度設計におい て考慮されるべき有用な情報となる。

また，特筆すべき点として，使用した分析モデルや データ, 前提条件等に含まれる不確実性に立ち戻り, そ れがリスク評価結果にもたら寸影響について考察を深め ているものが3報（No.18，21，28）あった. リスク評価 の結果から直ちに結論付けをするのではなく, 不確実性 の高いデータの振れ幅に対して感度解析等を実施して, より安全側に立って判定することは重要な手続きである.

\section{f） c-2 : リスクの経済活動への反作用の想定の有無}

化学物質の利用にかかわる組織のリスクをマネジメ ントする立場から捉えると, 環境・健康・生態リスクが 企業活動に及ぼす影響の経路, 寸なわち環境状態変化の 人間活動へのフィードバックも化学物質ーリスク連鎖上 にあるとの認識に立ち，それを評価範囲に包含させたリ スク評価が必要となる，そのため，その場合のエンドポ イントは組織の事業継続性となる ${ }^{19}$.

こうした側面に言及しているレポートが2報（No.5， 25）あり，それぞれ事業不認可という経営上のリスクと， 製品中一の有害物質混入による信用失墜リスクの可能性 が述べられている.しかし, 組織リスクまでの具体的な 波及経路や現実化の過程に関寸る考察には至っていない 排出事業主体にとってコンプライアンス上の失敗がクリ ティカルとなる時代であり,「化学物質のリスク管理= 組織のリスク管理」の図式は実社会でのリスク事例から 観察・実感することができるが，それらを明示的につな いでゆこうとする視点を読み取ることはできなかった。

\section{g) d : リスク管理に関する助言の熟度}

問題構造の理解に基づいて介入断面を明らかにして, リスク管理のための上流〜下流対策を多段的に提言して いるものが6報（No.5，9，12，14，18，34），対策費用 や費用対効果を算定している，もしくは対策の優先順位 付けをおこなっているものが7報（No.3，5，9，11，13， 30，21），さらに対抗リスクについて考察しているもの は1報（No.11）である. その他，具体的なリスク管理策 を提案しているレポートが3報（No.6，25，33）あり，
全体の40\%にあたる計14報が何らかの助言構築をおこな っている。しかしながら，そのうちの6報はリスク評価 の結果に基づいて立案された管理方略にはなっておらず, 組織や社会の意思決定, 合意形成に資するには科学的・ 合理的根拠を欠くものとなっている.

なお，分析対象としたレポートには見受けられなか ったが，急性・慢性毒性や生物蓄積性といった毒性の種 類によって規制の考え方や管理手法が異なることも, 助 言構築に反映させるべきである.

\section{h）評価者属性から見たライフサイクル思考の特徵}

表-1では, 評価者の基本属性として職種, 役職, 年齢 を整理している. レポート評価の結果からは, これらの 属性の違いによる評価結果に明確な差異を確認すること ができない，これは，LCAやリスク評価が必ずしも評価 実施者の主たる業務, 恒常的業務でないことなどに起因 すると推察される. したがって, これからの大学・大学 院は, 彼ら社会人の実務の質を向上させるという意味で も社会人受講生を積極的に受け入れ，LCAやリスク評価 に関する最新の知識やスキルを教授するためのカリキュ ラムの設計と，「社会人高度教育」プログラムのような 講義の運用も必要であろう.

\section{（2）教育カリキュラム改善への示唆}

まず， a-1〜b-2の結果では，化学物質のライフサイク ルに沿って全面的に物質の移動や漏出, 散逸を把握しよ うとする視点や姿勢を見出すことができなかった. しか し，LCAにおいてそうであるように，化学物質のリスク 評価でも寸べてのライフステージ, 物質, 経路, 影響を 対象とすることは, その労力や時間的およびデータ上の 制約から考えて現実的ではない.それゆえ，まずライフ サイクル全体を俯瞰し，影響の大きいプロセスや断面を 特定した上でリスク評価を深めていくという全体化の能 力, 寸なわち「俯瞰力」と「高い判断力」の涵養が必要 となる.このためには，1）環境リスクの原因となりう る組織活動を対象としたLCAやMFAの方法論的基礎を 教授するとともに，2）その結果側であるヒト・生態系 のリスク評価の技術体系を教育し，3）これらを，モデ ル企業の事業活動に伴うリスク要因を洗い出し, 問題を 構造化し，さまざまな場面を想定したリスク管理戦略を 作成していく演習20)などの講義と統合するようなカリキ ユラム設計が必要である.

次に，c-2の結果からは，化学物質がもたらす各種リ スクが，その排出主体の組織リスクとなりうるという因 果連鎖の構造を構想できる「思考力」を養う教育が求め られると言える，そのためには，例えば環境リスクが具 体的にどのように社会や企業にダメージを与えるかにつ いて，組織活動と環境リスクの因果関係を「見える化」 
するためのツール開発199や, 健康リスクや生態リスクが 企業・組織の継続性に無関係ではないことの理解を促す ための環境リスク事例 (ケース) 学習素材の開発など, 演習モジュールを有効に運用するためのコンテンツ開発 が必要となる.

最後に，d の側面に関しては，リスク評価から得られ た結果を社会的な文脈の中で捉え，企業・組織や社会の リスク管理計画の立案・策定に連結し，管理行為を実行 しうる「実践力」の育成が求められる。このためには, 実社会でさまざまなリスクに直面ないし関与している実 務の現場（企業など）において，現実的な問題や事例を 取り上げながら，多種多様なリスク感性を持つ主体との 共考のもと, リスクの抽出から評価，対応策の検討，コ ミュニケーションに至る一連の実践的過程を一体的に体 験・学習する, 実地研修型の場の構築を重視すべきであ ろう. 大阪大学のプログラムでは, ロールプレイによっ てリアリティのある場面や状況の下で当事者として立ち 振る舞うリスク・コミュニケーション, 対策立案・意思 決定演習を実施している21, 22)。こうした手法を有効に機 能させるためには, 各種の経験や知識を持つ人々が共学 寸るためのプラットフォームが必要であり, このモデル 開発が求められる.

\section{4. おわりに}

本論文では，化学物質のリスク評価を扱った教育演 習事例に基づいて，リスク評価に見られる被養成者のラ イフサイクル思考を分析した. その結果，1）物質一製 品流に沿ってリスク特定・評価を手がけ, ライフサイク ル全体をマネジメントの対象とするアプローチや視点が 少ないこと，2）評価結果に基づいてリスク管理方略を 多重, 多段に立案する能力とスキルの涵養には, 教育上 の改善の余地があること，3）化学物質由来のリスクが 社会や組織経営に及ぼす潜在的なダメージについては, 多くの被養成者の視野におさめられていないこと，4） 逆に，手順が確立され，道具立ても備わっている評価の プロセスでは適切な手続きが踏まれていること，が明ら かになった.

近年, 加工組立産業を中心に定着しつつある拡大生 産者責任（EPR: Extended Producer Responsibility）の思潮の もと, 素材産業や組立産業などの業種間連携で化学物質 管理が進む中にあって, 化学物質一製品チェーンでのリ スク管理と，そのためのリスク評価と LCA の統合的な アプローチのより一層の強化は, 組織リスクマネジメン 卜上の重要な課題となろう. 環境リスク教育がこうした 社会的潮流や要請に応えるためには，1）組織活動から
環境リスクまでの統合的評価に必要な「俯瞰力」と「高 い判断力」を涵養するためのカリキュラム設計，2）組 織活動と環境リスクの因果連鎖を見抜き，一体的なリス ク管理を立案して実行するための「思考力」の育成を支 援するコンテンツ開発，3）さまざまな社会経済的影響 をもたらす環境リスクに対して有効なリスク管理を遂行 していくための「実践力」を養成する共学プラットフォ 一ムの構築，の観点から教育システムの改善や高度化を 図る必要があると考えられる。

なお，本論文で題材としたリスク評価演習は，リス ク評価と LCA の統合を強く意図した講義を経た後に実 施されたものではなく, またレポート課題が LCA の手 続きを直接的に要求するものでない. したがって, リス ク評価におけるライフサイクル思考の実装がどのような 教育の効果として現れるかについては，明らかにしてい ない. 加えて, こうした思考, スキルがどのような学習 歴や業務経験によって培われるのかに関しても, 本論文 では追究できていない.さらに, 設定した判定項目やス キルレベルはプロトタイプであり, 科学的に確立された ものではない. これらの点は今後の研究課題としたい.

\section{謝辞}

本論文は，文部科学省科学技術振興調整費・新興分 野人材養成「環境リスク管理のための人材養成」プログ ラム（研究代表者: 盛岡通）の一環として実施された. 記して感謝の意を表す.

\section{参考文献}

1) 森口祐一：人間活動と環境をめぐる物質フローのシステ 么的把握，環境科学会誌，Vol.18，No.4，pp.411-418，環境 科学会, 2005 .

2) UNEP: Strategic Approach to International Chemicals Management SAICM texts and resolutions of the International Conference on Chemicals Management -2006 .

3) 経済産業省：「化学物質総合管理イニシアチブ」の提案, 2001. (入手先 : ‘http://www8.cao.go.jp/cstp/projectenv/env_pj4_shi ryo $>, 2010$ 年 1 月 15 日参照)

4) 星川欣孝, 増田優 : 化学物質管理能力の拔本的強化構想 一化学物質総合管理体系への枠組みの変革一, 化学生物 総合管理, Vol.1, No.2, pp.271-279, 化学生物総合管理学 会, 2005.

5) 増田優 : 化学物質総合管理を越えた新たな潮流一基盤の 整備と人材の教育一, 化学生物総合管理, Vol.1, No.3, pp.428-440, 化学生物総合管理学会, 2005.

6) 大阪大学「環境リスクマネジャ養成プログラム」ウェブ サイト，〈http://risk.see.eng.osaka-u.uc.jp〉（2010 年 1 月 15 日参 照)

7) 横浜国立大学 安心・安全の科学研究教育センターウェブ サイト，〈http:/www.riskunit.ynu.ac.jp〉（2010 年 1 月 15 日参 照) 
8) お茶の水女子大学 ライフワールド・ウオッチセンターウ エブサイト，〈http://www.lwwc.ocha.ac.jp/saikyouiku〉（2010 年 1 月 15 日参照)

9) 盛岡通，齊藤修 : 環境リスク管理教育の動向と社会ニー ズ，プレミアムシンポジウム予稿集・最終成果報告書 「リスク管理教育が導く持続可能社会」，pp.128-134, 2008.

10) European Commission: European Union: Risk Assessment Report, 2004.

11) Tukker, A.: Risk Analysis, Life Cycle Assessment - The Common Challenge of Dealing with the Precautionary Frame (Based on the Toxicity Controversy in Sweden and the Netherlands), Journal of Risk Analysis, Vol.22, No.5, pp.821-832, 2002.

12) Matthews, S. H., Lave, L., MacLean, H.: Life Cycle Impact Assessment: A Challenge for Risk Analysts, Journal of Risk Analysis, Vol.22, No.5, pp.853-860,2002.

13）横浜国立大学 化学物質リスク管理情報基盤研究プロジ エクトチーム : 化学物質のライフサイクルにわたるリス ク評価のための新たな研究と情報整備, 環境情報科学, Vol.37, No.3, pp.64-67, 環境情報科学センター, 2008.

14) 産業構造審議会 化学・バイ才部会化学物質管理企画小 委員会 : 化学物質総合管理のための体制整備について一 人材育成と教育のあり方一中間報告, 2002 .

15）東野晴行, 北林興二, 井上和也, 三田和哲, 米澤義暁 : 暴露・リスク評価大気拡散モデル（ADMER）の開発，大 気環境学会誌, Vol.38, No.2, pp.100-115, 大気環境学会, 2003.

16）石川百合子，東海明宏 : 河川流域における化学物質リス ク評価のための産総研一水系暴露解析モデルの開発, 日
本水環境学会誌, Vol.29, No.12, pp.797-807, 日本水環境学 会, 2006.

17) 産業業技術総合研究所・安全科学研究部門ウェブサイト, $\measuredangle \mathrm{http}: / / w w w . a i s t-r i s s . j p / p r o j e c t s / R L 〉 ，(2010$ 年 1 月 15 日参照）

18）産業業技術総合研究所・安全科学研究部門ウェブサイト, $<$ http://www.aist-riss.jp/software/riskcat>，（2010 年 1 月 15 日参 照)

19) 松井孝典, 松村憲一, 織田朝美, 加藤悟, 原田要之助, 盛岡通 : 組織のサステイナビリティマネジメントを指向 した環境リスクマネジメントシステムの開発，日本リス ク研究学会第 21 回研究発表会講演論文集, Vol.21, pp.475480, 日本リスク研究学会, 2008.

20）加藤悟，松井孝典，松村憲一，織田朝美，盛岡通 : リス クマネジメント教育のためのケースメソッドの開発，日 本リスク研究学会第 21 回研究発表会講演論文集, Vol.21, pp.423-427, 日本リスク研究学会, 2008.

21）松村憲一, 土屋智子, 田中豊, 久鄉明秀, 松井孝典, 織 田朝美, 加藤悟, 盛岡通 : リスクコミュニケーション教 育の実践, 日本リスク研究学会第 20 回研究発表会講演論 文集，Vol.20，pp.107-112，2007.

22）松村憲一，織田朝美，大野智彦，松井孝典，加藤悟，盛 岡通 : リスクマネジメント教育における模擬クライシス コミュニケーションの実践, 日本リスク研究学会第 21 回 研究発表会講演論文集, Vol.21, pp.449-452, 日本リスク研 究学会, 2008 .

(2009. 10.30 受付)

\title{
ANALYSIS OF LIFE CYCLE THINKING IN CHEMICAL RISK ASSESSMENT BASED ON PRACTICES IN EDUCATION PROGRAM ON ENVIRONMENTAL RISK MANAGEMENT
}

\author{
Yugo YAMAMOTO, Takanori MATSUI, Asami ORITA, Ken'ichi MATSUMURA, \\ Tomohiko OHNO, Satoru KATO, Akihiro TOKAI and Tohru MORIOKA
}

In this paper, we developed seven judgment criteria to evaluate the degree of life cycle thinking observed in risk assessment practices. We also conducted an analysis of life cycle thinking based on 35 technical reports prepared by students of the "Environmental Risk Management Training Program" at Osaka University. The results of this analysis showed that almost all students conducted the environmental fate and risk assessment of chemicals released from individual production processes but they did not consider the life cycle impacts of the chemicals-product chain.

From this study, we reached the following conclusions: 1) few students used the life cycle thinking of the chemicals-product chain into the view of risk management, 2) the development of human resource is needed with specialised knowledge and skills to plan multiple strategies for risk management based on the results of risk assessment, 3) descriptions on the potential damages from risks derived from chemical substances to the organizational and social systems were absent from the large majority of the technical reports on risk assessment, and 4) on a positive note, that appropriate procedures were followed by the students in the assessment processes where methodologies had already been established. 